\title{
ヒト細胞に打ける蛍光小体の研究
}

東京医科蔯科大学泌尿器科教室 酒 井 邦 彦
(主任 : 溚合京一郎教授)

\section{INVESTIGATION OF FLUORESCENT BODY IN THE HUMAN CELLS}

\author{
Kunihiko Sakai \\ Department of Urology, School of Medicine, Tokyo Medical and Dental University
}

(Director; Prof. K. Ochiai)

Recently evidence, that $\mathrm{Y}$ chromosome with strong fluorescence can be distinctly distinguished from another chromosome on the metaphase plates of cultured human blood stained with quinacrine mustard dihydrochloride or quinacrine dihydrochloride (fluorescing dye-stuffs) and also a fluorescent spot in the similarly prepared interphase nuclei of various human cells can be observed through the fluorescence microscope, has been published and confirmed. The fluorescent spot in the interphase nucleus is thought to indicate the existence of $\mathrm{Y}$ chromosome and is called "fluorescent body", and its clinical usefulness is suggested

The author investigated the fluorescent body in nuclei of somatic cells (mainly hair-root cells), lymphocytes of systemic blood and in spermatozoon with the fluorescence microscopic method.

1) Distinct fluorescence was recognized at the distal portion of $Y$ chromosome long arms on the metaphase plate of cultured human lymphocytes stained with quinacrine.

2) In nuclei of hair-root cells as well as lymphocytes in the systemic blood obtained from normal male, a round or oval bright fluorescent body in diameter from $0.2 \mu$ to $0.3 \mu$ was regularly observed and the average incidence of the fluorescent body was more than 40 percent of the cells examined. The incidence did not show the correlation to the age. In contrast to these findings, the fluorescent body usually could not be recognized in the nuclei of the somatic cells from women. If present at all, the incidence was in less than 3-4 percent.

It was reasonably concluded that the examination of the fluorescent body in the interphase nuclei of human somatic cells offered a very useful clinical method for determination of cytogenetic sex, and that combined examination of Barr body at the same time gave more accurate information for this purpose.

3) Spermatozoon with single fluorescent body which showed similar appearance in the interphase nuclei of somatic cells were observed in $40-45$ percent. The incidence showed no correlation to sperm count or sperm motility of the sperms from the normospermics and oligospermics. In eight specimens, which were obtained from four normospermics and four oligospermics, spermatozoon with two fluorescent bodies were recognized. The average incidence was 1.8 percent. But double fluorescent body was observed more often in morphologically anomalous spermatozoon than in normal structured ones.

4) The incidence of fluorescent body in human somatic cells from patients with simple hypospadia, cryptorchidism, male infertilities and male hermaphorditism was on the same level as that of normal male, whereas female hermaphrodites showed the same level of incidence of fluorescent body as that of the normal female.

5) In true hermaphroditism, the incidences of fluorescent body and Barr body were almost in accordance with their karyotype, but showed lower level than that of normal men and women. In true hermaphrodites with mosaicism and mixed gonadal dysgenetic patients, the incidences of both bodies were generally low and sometimes the cytologic sex could not be determined from the examination of these nuclear bodies. The results would suggest that the patient might be true hermaphroditism or 
mixed gonadal dysgenesis.

6) The incidence of fluorescent body in patients with Kleinefelter's syndrome (all cases, 47, XXY, positive Barr body) was as high as that of normal men. It might be thought that the high incidence of fluorescent body corresponding with that of normal male with positive Barr body was a characteristic cytological feature in Kleinefelter's syndrome.

\section{まえがき}

体細胞核に認められる sex chromatin（あるいは drumstick) による，いわゆる細胞学的性別（cytologic sex） の判定はすでに routine の検索法として臨床的にも広く 利用されている ${ }^{8)}$. 一方最近に至り植物（ダイズなど） や動物（ハムスターなど）の細胞をアクリジン色素によ る䖢光染色法で研究していた学者らによつて, 染色体の 部分部分がいくつもの带状に蛍光染色されることが発見 された ${ }^{2) 31}$ 。これにひきつづき，さらにヒトのリンパ球 培盖による分裂中期の染色体を営光染色すると，Y染色 体だけがとくに強い䖢光を発して他の染色体と容易に区 別できるという極めて興味ある成績が発表された ${ }^{7222}$. この研究は直ちにP Pearson ら ${ }^{13)}$ にって追試確認され, とくに強い蛍光を発するのはY 染色体の長腕の遠端の半 分であることが確かめられた．これはさらに Caspersson $ら^{5)}$ によつても追試確認されている。 しかも口腔粘膜剥 離細胞の interphase の細胞核でもはつきり之強い䖢光を 発する小体の存在することも報告された。これらの研究 成績から，この小体は学光小体 (fluorescent body), 略し てF小体（F body）などと呼ばれ，さらにその後の検 索によつて F 小体の存否は $\mathrm{Y}$ 染色体の存否, い小か光る と体細胞に扣ける Barr 小体 (sex chromatin) と同様に 細胞学的性別判定に空用できることが明らかにされるに 至つた.

著者は営光色素である quinacrine dihydrochloride 拉 よび quinarine mustard dihydrochloride 染色法によつ て, 正常男女拈よび各種の性器系異常に拈ける体細胞あ るいは精子などについてこの F 小体を検索した．との結 果この検查法が Barr 小体と同じく, 細胞学的性別の判 定に極めて有用な方法であることを確認したほか，若干 の興味ある所見も検索しえた.

\section{検索材料と検索方法}

検索の対象は，対照としてほぼ各年令層にわたる性别 のはつきりした正常男女55例 (男31例，女24例)，先れに 男子不妊症, 性染色体異常, 性器奇形あるいは半陰陽の 99例, 計 154例である.

（1） 後述するように細胞核の F小体はいろいろな細 胞, たとえば口腔粘膜剝離細胞, 毛根細胞, 血液あるい
は精液中の精子などで検索できる。これらからの標本は 以下のような方法で作製した。

(a) 粘膜剝離細胞扣よび血液標本

Barr 小体の検索用標本作製 と同じようにスライドグ ラスに塗抹後, 室温で乾燥しメタノールで固定して染色 する.

(b) 毛根細胞標本

Schmid $^{18)}$, Meredith ${ }^{11)}$ およひび Sperling ${ }^{19)}$ の方法に準 拠して作製した．すなわち，側頭部から $2 \sim 3$ 本の毛髮 をひき抜き，毛根部を残して剪除しこれを直ちに $2 \sim 3$ 滴の60\%酢酸溶液を滴下したホール・グラスに浸たす。 ほぼ 5 分間で毛根外層の細胞の殆んど全部は酢酸溶液中 に遊離してくるが，なるべく多数の遊離細胞を得るため ピペットでごく静かに 4 〜 回溶液の出し入れを行な う、次にピペットに吸引した溶液を脱脂肪したスライド グラス上に滴下塗抹し，これを室温で空気乾燥させる。 この操作によつて 1 枚の標本で抢よそ300個の剝離細胞 を観察することがでさる。

（c）精子標本

添涪 Barlow \& Vosa ${ }^{11}$ に準拠したが，実際にはいろい ろと検討を加えた結果，以下のような操作で標本を作製 した，新鮮な射精液が均質に液化するのを待ち，その 1 $\mathrm{ml}$ 飞約 $10 \mathrm{ml}$ の生理食塩水を加光て 3,000回転で 3 分 間遠沈して上清をすて, 再び生理食塩水を追加して同じ ように遠沈を行なう，その上清をすてた後に Carnoi 液 3〜 $4 \mathrm{ml}$ を加光る. この液を駒込ピペットで静かに出 し入れして精子を均等に浮遊させ，その $2 \sim 3$ 滴をピペ ットでスライドグラス上に落し速かに火炎乾燥させる.

（2）染色法と検索法

細胞核の F 小体の染色には acridine 色素に属する quinacrine mustard dihydrochloride (以下 QM と略記す る）および quinacrine dihydrochloride（以下Qと略記 する）が応用されている(図 1 参照)。この両種の色素は 後述するようにどちらも $\mathrm{F}$ 小体の検索用色素として応用 できるが，Qは QMにくらべてその蛍光度とか染色安定 度が劣ることは多くの学者がこれを承認している．著者 も研究の初期には QM の入手が極めて困難であつたた め, 専らより入手しやすいQにより検索を行なつた。 そ 
図 1<smiles>CCCC1C2CCCCC2NC2CC(Cl)CCC2C1NCC</smiles>

QM dihydrochloride<smiles>CCNC1C2CCC(Cl)CC2NC2CCC(OCC)CC21</smiles>

Q dihydrochloride
の後QM の入手が比較的容易になつたので最近では主と してQMによつて検索している. このQとQMを比較し た著者の成績でも，上述のように両者に優劣のあること

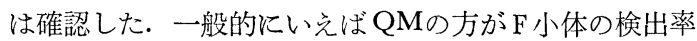
がやや高いといえる.しかし，どちらも heterochromatin 部分を染色するといら性質は同じであり，したがつて検 索に習熟してくればQによる染色標本でも臨床的には十 分に応用しうることを認めている.

標本の染色は次のようにして行なう。 $0.5 \%$ の溶液 では 6〜 7 分間， $\quad 0.005 \%$ QM溶液では20分間標本を 染色し, 脱イオン水で水洗し余分の色素を十分に洗い落 とし，直ちにpH 5.4の Mcllvain's buffer をのせカバー グラスをかけて封入する.

$\mathrm{F}$ 小体の検索には Zeiss の営光顕微鏡，光源としては HBO 200の水銀灯, BG 12の励起フィルター拈よび 530 $\mathrm{nm}$ の barrier filter を使用し油浸にて鏡検した。 ただ し，国産の Nikon 蛍光䫓微鏡も現在著者が使用してい る型式は Zeiss のそれと全く同等の性能をむつているこ とを確認している。 とくに Nikon 型は水銀灯の交換に好 都合である.

$\mathrm{Q}$ も $\mathrm{QM}$ も $\mathrm{F}$ 小体の検索には十分応用できるが，明ら か後者の方が裉色時間が長く安定している．たざQの 場合にはなるべく早く鏡検を完了するよう心がければよ く，少くとも20〜30分なら十分観察に耐兄らることがで きる.したがつてこのような注意の下に観察に慣れてく れば，Qあるいは QMどちらの染色標本によるF小体検 索成績でも，検出率に多少の差はあるが確実さに打いて 活とんど差はないことを確認している（図 2，3）.

なお，上述したどの種類の標本も $\mathrm{Q}$ または $\mathrm{QM}$ 染色で $\mathrm{F}$ 小体が明瞭に染色されるが，F小体の検索には標本に

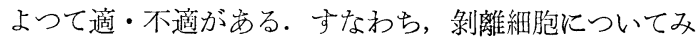
ると口腔粘膜細胞は十分に口をすすがせても細菌の混在 を除去することは難しく，しかもこの細菌も強く蛍光染 色され識別を困難にすることが多いという久点があり， $\mathrm{F}$ 小体の検索用としては不適で，この点では毛根細胞に よる標本が適している。したがつて，著者は剝離細胞に
図 2 毛根細胞核の $\mathrm{F}$ 小体出現率（正常）

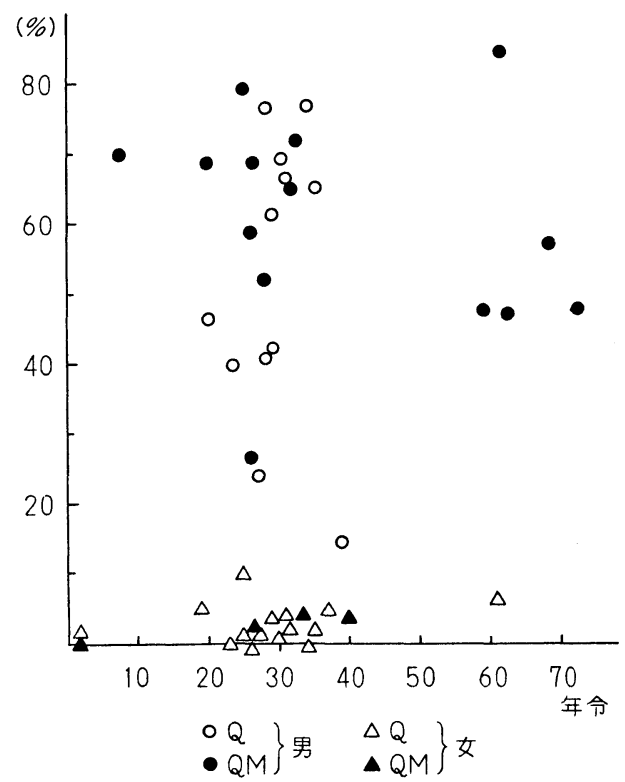

図 3 リンパ球の $\mathrm{F}$ 小体出現率（正常）

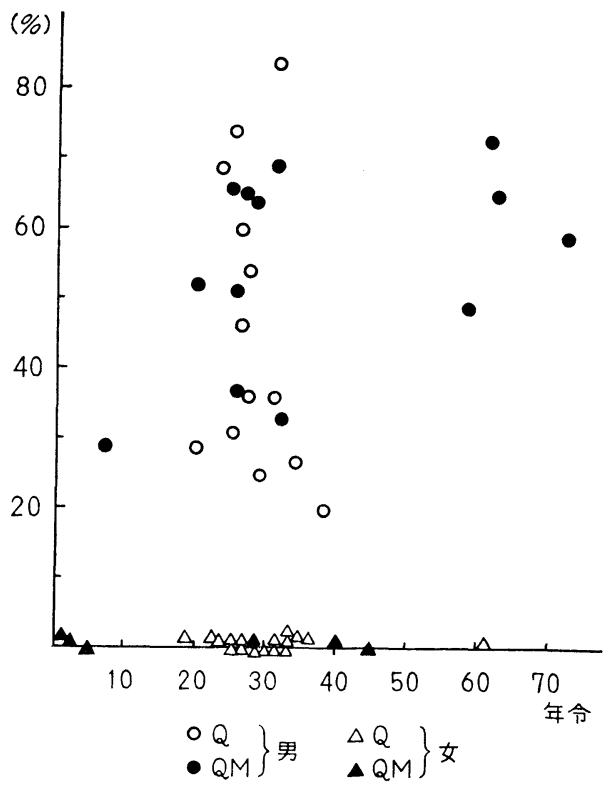

ついての F 小体検索は専ら毛根細胞によつた（写真 1 ). 血液塗抹標本では Barr 小体 (drumstick) と同様に多形 核白血球でも検索可能ではあるが紛わしいことが少なく なく, この点では核質も比較的均等なりンパ球の方が適 しており, 著者は専らリンパ球について検索した（写真 
$2,3)$.

\section{検索成縇}

口腔粘膜細胞標本 (buccal smear) でも F 小体の検索 は可能であるが，上述したように混在する細菌群も強く 蛍光を発するため鑑別に煩わしいところが少なくなく, $\mathrm{F}$ 小体の検索にはあまり適していない。ここでは専ら毛 根細胞についての検索成績について記述する。

(1) 正常男 - 女子

年令は 1 才から72才まで（大部分は20４0才代）, 臨怵 的にも性別に疑点のない男女合計55例について検索し た.

(a ) 毛根細胞核にお护る小体

第 2 章の（b）で述べた方法で作製した標本による と, 毛根細胞核には細長い形, 楕円形およびほぼ円形の 3 種類が認められる，F 小体はいずれもほぼ同じではある が，一般的にいらと棈円形細胞核が $\mathrm{F}$ 小体検索には適し ている. 1 枚の禋本には少くとも100～300個以上の豩離 細胞が存在しているが，原則としては 100個の細胞を観 祭してF小体の出現率を算出し，必要に応じては同時に 作製した別の標本についても検索し200個についての出 現率をも算出した。毛根細胞核に拈ける $\mathrm{F}$ 小体はbuccal smear 標本と本質的に異なるところはなく大きさ 0.2 $0.3 \mu$, 核質内に存在する場合は円形に, Barr 小体と 闹じく核質の内側に接して存在する場合はやや細長く桿 状に近い形を示していることが多い（写真1).しかし， いずれもその他の部分にくらべて強い蛍光を発してお り，その識別は極めて容易である.

男子の毛根細胞核における $\mathrm{F}$ 小体の出現率は14 84\% とかなりのゆがある。このらち30\%以下のものは検索初 期のもので，ごく少数例にすぎず，検索例の大部分は40 \%から75\%の間の出現率を示した.これに対し女子の細 胞核ではその過半数が全くF小体の出現を示していな い.しかし少数例では数\%の出現率（最高は10\%）であ り、これら全体を平均すると女子における毛根細胞核の F 小体の出現率は $2.9 \%$ となる (図 2 をも参照).ただ数 \%といら隄性率を示したものでも，その大部分に执いて 著者が $\mathrm{F}$ 小体と判定したものは蛍光跂度や大ささなどの 点で男子における $\mathrm{F}$ 小体とくらべると必ずしも典型的な 形状とはいえない印象が強かつた。したがつて, これ が男子細胞核に出現する F小体と全く同じものかどらか は判定しがたいが，いずれにしろ F 小体の出現率は男女 の間では明らかにちがつているといらことができる（後 述のリンパ球検索成績をも参照).また, 年令による出現
率の差は認められない.

（b）血液塗抹標本に打汁る $\mathrm{F}$ 小体

血液塗抹標本においては多形核白血球にも $\mathrm{F}$ 小体が出 現している. しかし後述のようにこの白血球では核にく びれや突起があり，さらに核質にも多少濃淡の差があ り蛍光部分の識別に困難を感ずることが少くない（写真 2, a， b). したがつて F 小体の検索に多形核白血球を 利用することは可能であるが，核質が均等な単核球（リ ンパ球）の方がはるかに明瞭に識別できる，著者は専ら リンパ球について $\mathrm{F}$ 小体の出現率を検索した. リンパ球 における $\mathrm{F}$ 小体の形状ははつきり周国と区別できる強い 省光を示す大きさ $0.2 \sim 0.3 \mu$ 程度の円形の小体として 劷められる. 大ていは核内に遊離して存在するが，とき には核膜内側に接して存在するものもある（写真 $3 \mathrm{a}$, b).

リンパ球にお忛る $\mathrm{F}$ 小体の出現率は男子では20〜 $84 \%$ であつた（図 3 ).このらち最低の $20 \%$ とか $30 \%$ 以下のも のは恐らく標本の不出来あるいは蛍光顕微鏡の水銀灯出 力の弱化が原因ではないかと考えられるもので，それ以 外ではほとんど大部分が30〜70\%といら数字のところに 集中している.これに対し，女子の場合にはF小体の出 琴率は 0 〜 $3 \%$ と低く平均值は $0.8 \%$ であり過半数では 全く $\mathrm{F}$ 小体は存在していない.すなわち, リンパ球で観 察した場合， $\mathrm{F}$ 小体の出現率は毛根細胞のそれと同様に 男女で明かに差がある。また年令による出現率の差は認 められない(図3).

このように，毛根細胞あるいはリンパ球に和ける $\mathrm{F}$ 小 体の出現率には確かにはつきりした男女差があるといら ことができる.ただ標本作製上の不手際とか営光顕微鏡 の水銀灯の性能などの原因によることもあつて，柾端に 出現率の低いごく少数例は別として男子の場命にも20～ $30 \%$ と出現率が比較的に低い与のも存在する。また间じ ように，女子でもほとんどその全部は細胞核に F 小体の 计現をみておらないが，少数例では2〜3\%から数\%と いら出現率を示すものもある。これは後述する半㓌塆例 ではしばしばみられる。同じような現象は Barr 小体の 場合にも観察されている。 しかし，いま男女別でリン八 球と毛根細胞におけるF 小体の出現率をそれぞれ縦槛い 夾標軸上にとつてみると，図４のような関係を示してい る.すなわち，仮りに男子の場合どちらかの出現摔が低 かつたとしても, 同一人については常に一jの出現垶は 宫く，これに対し女子の場合にも仮りにどちらかがやが 高い出現率を示しても他方は低率といら関係をもつてい 


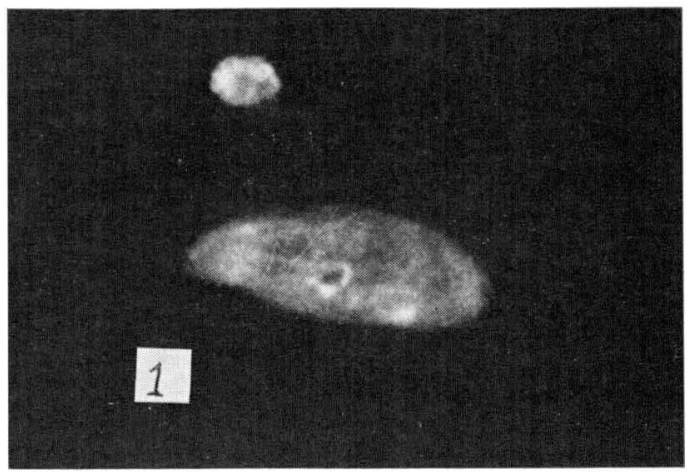

写真 $2 \mathrm{a}$ ：多形核向血球の $\mathrm{F}$ 小体（油浸 $\times 800 ）$

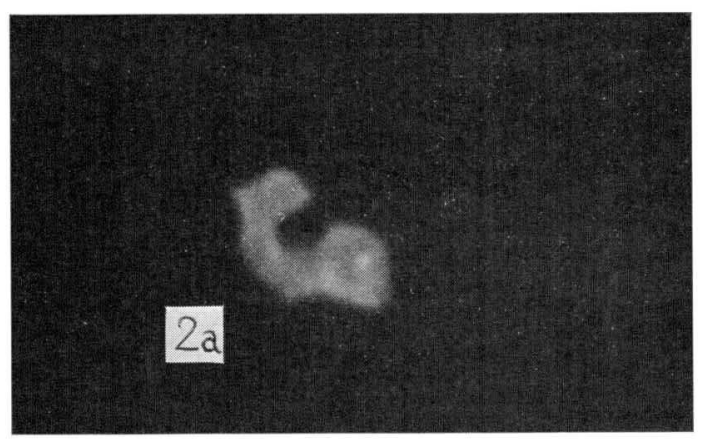

写真 $3 \mathrm{a}$ ：リンパ球の $\mathrm{F}$ 小体核質内にある

(油浸 $\times 1000)$

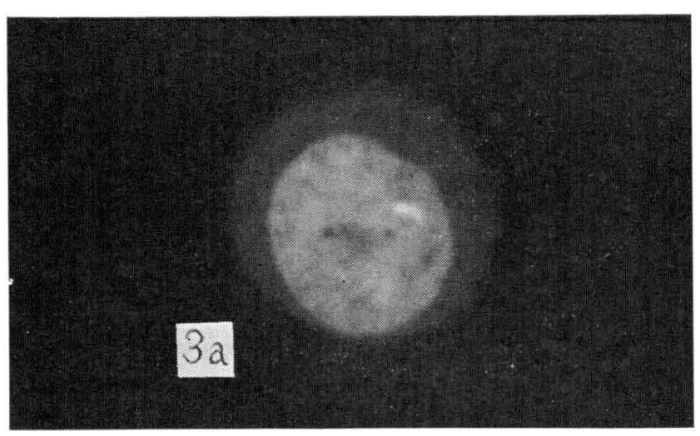

写真 $2 \mathrm{~b}$ ：多形核白血球の $\mathrm{F}$ 小体核膜の内側に按して 存在（油浸 $\times 800 ）$

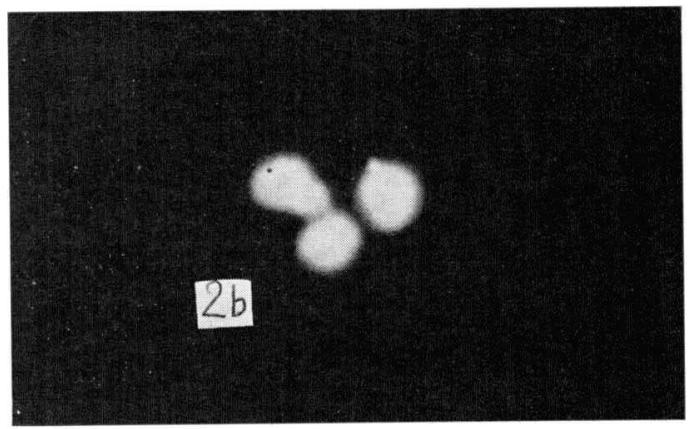

写真 $3 \mathrm{~b} ：$ リン゚球の $\mathrm{F}$ 小体核膜の内側に接して存在 (油浸 $\times$ 800)

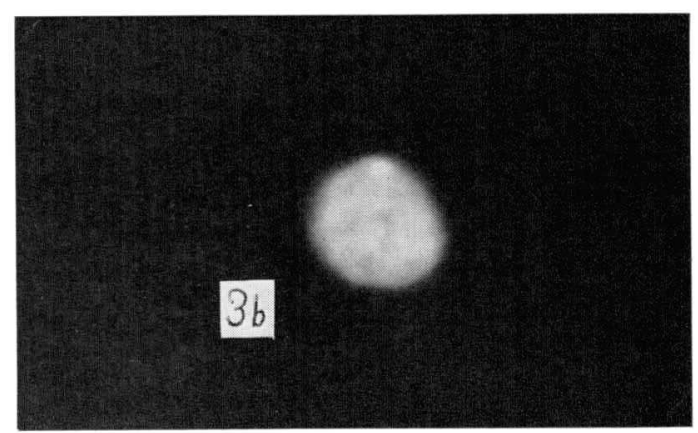




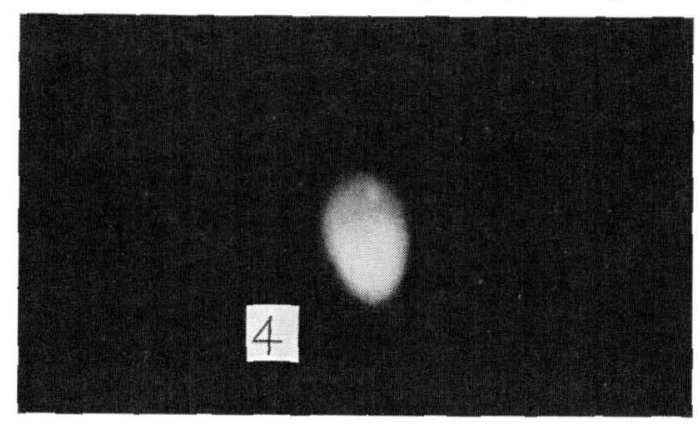

写真 5：2 個の $\mathrm{F}$ 小体をもつ精子形態は異常老呈 与る。(油浸 $\times 1000)$

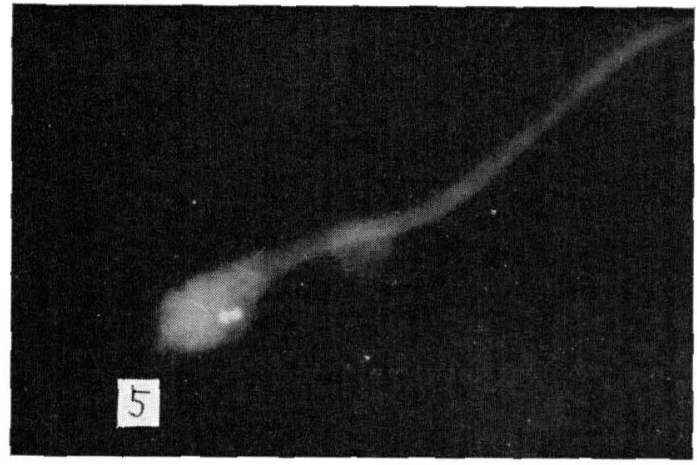

る.したがつて,この座標軸にプロットすれれば，男女の 間でF小体の出現率にはつきりした差のあることが判か る、Barr小体の検索と同様によい標本，よい頙微鏡，よ い眼ということが $\mathrm{F}$ 小体検索の場合もその基本条件でめ ることはいうまでもないが，F小体による細胞学的性別 の判定に際し，確実を期するためには同一人のリンパ球 と毛根細胞についての成縝至総合して判断するのがよい といえる。

（c）精子にお杍るF小体

材料怔常精子数（4,000万/ $\mathrm{ml}$ 以上）の子の26例と 乏精子数（ 4,000 万 $/ \mathrm{ml}$ 以下）のもの21例で, これらに つき睡述の方法（第2 章のc参照）によつて精子に执け る F小体を検索した。な抢,これら射精液については精 子数の汪か運動性, 形態の異常なども併せて検萦した。 精子染色標本で観察でさる精子数は正常か高度の乏精子
写真6：ヒト・リンパ球の培美細胞（QM染色，油浸 $\times 1000 ）$ 染色体の最も左侧にあるのが $\mathrm{Y}$ 染色 体で，その長腕の遠端の約半分が強い监光老首 発している(外村教授による)。

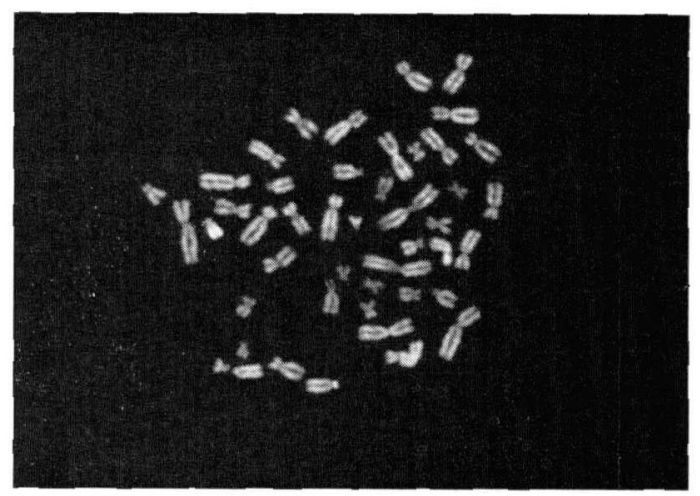

症かで異なるが，正常なものでは1枚の標本で優に 300 個の精子数を娭索でさ, 高度のものを除く中等度の乏精 子数の䧣本でも汪淰 100～200個は常に観察することが できる。F小体の出現率は原則として 100個の精子につ いて算定した.

精子をQあるいはQMで染色すると，一般に頭部の前 半部は淡く後半部はそれより濃く黄色調に染まる。 F小 体は極めて强い省光を発する直径 $0.2 \sim 0.3 \mu$ の円形微 小体として現われ，周囲とははつきり区別することがで きる、頭部に拈けるその存在部位は必ずしも一定してい ないが，大部分では磌部の中間で Achrosome との境界 近くに位置していることが多い(写真4).

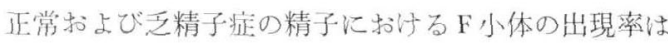
2 例（5\%および10\%）を除さ，てれ以外のものではほ とえど全部30４0\%の間に集中して扣り，最高は49\%て あつた（図5）。あるいは $5 \%$ および10\%といら低出現率 
図 4 リンパ球および毛根細胞におけるF小体出現 率男女差（正常）

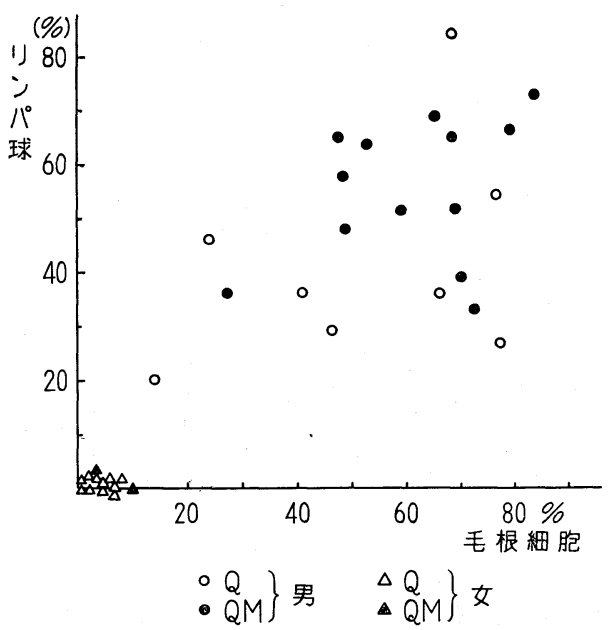

図 5 精子の $\mathrm{F}$ 小体出現率と精子数

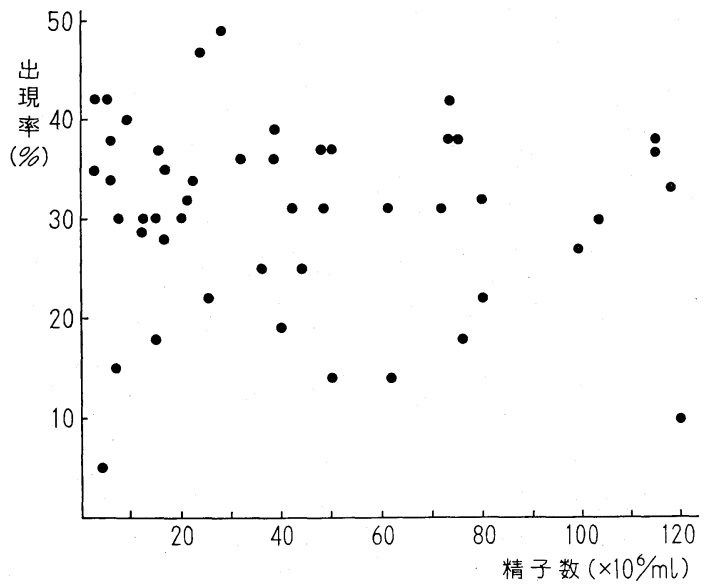

のものは標本作製あるいは鏡検上の不備によるものかも 知れない. したがつて一般的には精子のらちその $40 \%$ 前 後はF小体をもつものであるといらことができる。また この出現率は精子数拈よび運動性との間に相関関係を示 していない（図 5,6).

とくに注目すべき所見は，すべての精子についてでは ないが検索した47例のうち 8 例の精液（正常 4 例, 乏精 子症 4 例）に拈いて精子のなかに，2 個の $\mathrm{F}$ 小体をもつ ものが存在するといらことである.この 2 個の F 小体は 大きさも蛍光度もほとんど同じではあるが，2 個は近接 していても融合していることはない（写真 5 ). その出 現頻度は 2 個の $\mathrm{F}$ 小体をもつ精子の精液に扣いて $1 \sim 3$
図 6 精子の $\mathrm{F}$ 小体出現率と運動性

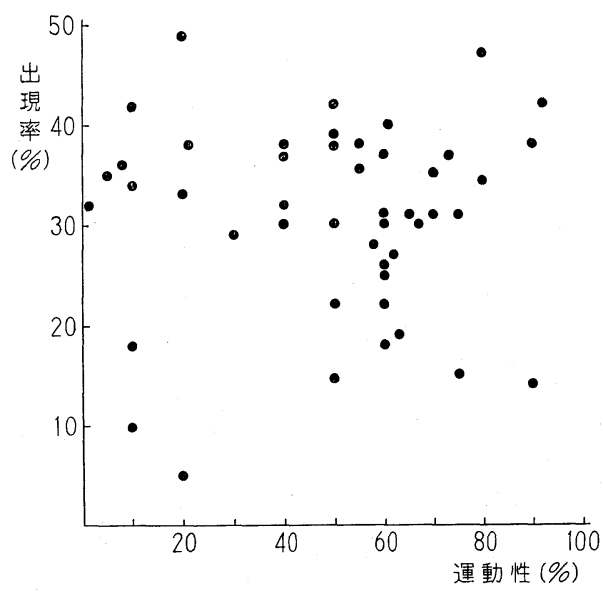

$\%$, 平均 $1.8 \%$ といら数字を示した。 をれには形態正常 の精子にも 2 個の $\mathrm{F}$ 小体をもつものがあるが，全般的に みると 2 個の $\mathrm{F}$ 小体をもつ精子は大形でやや変形したい わゆる形態異常精子の方に多くみられる傾向が強い（写 真 5 ).

（d ）乏精子症, 単純性尿道下裂, 停留辠丸, 半院陽 おっび性染色体異常症におけるF小体。

(i ) 乏精子症

精子数が 2,000 万 $/ \mathrm{ml}$ 末満のものを乏精子症とした. （c）にも述べたように，精子に打汁る F 小体の出現率 は正常执よび乏精子数に特いて差異はなかつた（図 5 を 参照).ここでは比較的高度の乏精子症 $\left(20 \times 10^{6} / \mathrm{ml}\right.$ 以 下）のものについて毛根細胞拉よびリンパ球の F 小体出 現率を検索した。 その平均值はそれぞれ $52.3 \%$ 执よび 31.1\%を示しており，これらは正常男子のそれと同様で

表 1 至精子症火に拈ける体細胞の $\mathrm{F}$ 小体

\begin{tabular}{|c|c|c|c|c|c|}
\hline \multirow{2}{*}{ 症 } & \multirow{2}{*}{ 例 } & \multirow{2}{*}{ 年 } & \multirow{2}{*}{ 令 } & \multicolumn{2}{|c|}{$\mathrm{F}$ 小体 $(\%)$} \\
\hline & & & & 毛根細胞 & リンパ球 \\
\hline & 1 & & & 43 & 50 \\
\hline & 2 & & & 53 & 29 \\
\hline & 3 & & & 75 & 38 \\
\hline & 4 & & & 25 & 39 \\
\hline & 5 & & & 54 & 32 \\
\hline & 6 & & & 1 & 26 \\
\hline & 7 & & & 53 & 26 \\
\hline \multirow{2}{*}{\multicolumn{2}{|c|}{8}} & & & 63 & 9 \\
\hline & & 平 & 均 & 52.3 & 31.1 \\
\hline
\end{tabular}

* 精子数 : $20 \times 10^{6} / \mathrm{ml}$ 以下のもの 
あつた（表 1 ）。

ii) 単純性尿道下裂

Barr 小体陰性の単純性尿道下裂 6 例についての毛根細 胞あるいはリンパ球における $\mathrm{F}$ 小体の出現率の平均值は いずれも $66.2 \%$ 抢よび $49.8 \%$ を示して打り，これらは正 常男子のそれと同様であつた（表 2 ）.

iii) 停留辠丸

Barr 小体陰性で他に奇形を伴わない停留辠丸 6 例飞つ いての毛根細胞あるいはリンパ球における F小体の出現 率の平均值は62.6\%よび60.2\%を示して招り，これらは 正常男子のそれと同様であつた（表 2 ）。

表 2 単純性尿道下裂および停留辠丸における 体細胞の $\mathrm{F}$ 小体

\begin{tabular}{l|ll|l}
\hline \multirow{2}{*}{ 症 例 } & 年 & \multicolumn{2}{|c}{$\mathrm{F}$ 小体 $(\%)$} \\
\cline { 3 - 4 } & & 毛根細胞 & リンパ球 \\
\hline
\end{tabular}

尿道下裂

\begin{tabular}{|c|c|c|c|}
\hline 1 & 6 & 50 & 49 \\
\hline 2 & 4 & 1 & 50 \\
\hline 3 & 6 & 51 & 34 \\
\hline 4 & 2 & 75 & 62 \\
\hline 5 & 3 & 82 & 58 \\
\hline \multirow[t]{2}{*}{6} & 4 & 75 & 46 \\
\hline & 平均 & 66.2 & 49.8 \\
\hline
\end{tabular}

停留鲜 丸

\begin{tabular}{c|c|c|c}
\hline 1 & 28 & 61 & 56 \\
\hline 2 & 22 & 55 & 65 \\
\hline 3 & 20 & 35 & $/$ \\
\hline 4 & 5 & 88 & 50 \\
\hline 5 & 4 & 75 & 46 \\
\hline 6 & 10 & $/$ & $84^{*}$ \\
\hline & 平 均 & 62.6 & 60.2 \\
\hline
\end{tabular}

*: QM染色

iv）男性半陰陽.

Barr 小体は陰性で臨床的に男性半陰陽の確診がつけら れた 6 例についての毛根細胞あるいはリンパ球に招ける $\mathrm{F}$ 小体は $52.0 \%$ 拉よび $49.3 \%$ の出現率で，正常男子のそ れと同様であつた。このうち染色体分析を行なつたるの は 1 例で46XY であつた（表 3 ).

v) 女性半陰陽

先天性副腎過形成症 2 例と非進行性女性半陰陽 2 例况 ついての毛根細胞およびリンパ球に括ける $\mathrm{F}$ 小体の出現

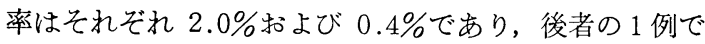

表 3 男性半陰陽*における体細胞の $\mathrm{F}$ 小体

\begin{tabular}{|c|c|c|c|c|c|}
\hline \multirow{2}{*}{ 症 } & \multirow{2}{*}{ 例 } & \multirow{2}{*}{ 年 } & \multirow{2}{*}{ 令 } & \multicolumn{2}{|c|}{$\mathrm{F}$ 小体 $(\%)$} \\
\hline & & & & 毛根 細胞 & リンパ球 \\
\hline & 1 & \multicolumn{2}{|c|}{5} & 61 & 61 \\
\hline & $2 \Delta$ & \multicolumn{2}{|c|}{20} & 34 & 41 \\
\hline & 3 & \multicolumn{2}{|c|}{3} & 1 & 61 \\
\hline & 4 & \multicolumn{2}{|c|}{6} & $\zeta$ & 60 \\
\hline & 5 & \multicolumn{2}{|c|}{10} & 46 & 47 \\
\hline \multirow{2}{*}{\multicolumn{2}{|c|}{6}} & \multicolumn{2}{|c|}{29} & 67 & 26 \\
\hline & & 平 & 均 & 52.0 & 49.3 \\
\hline
\end{tabular}

※: Barr 小体㤬全例とも陰性

ム: kayotype が46, XYと確認されたもの.

表 4 女性半陰陽に抢汀る体細咆の $\mathrm{F}$ 小体

症 例 $\mid$ 年 含 $\left|\frac{\mathrm{F} \text { 小体 }(\%)}{\text { 毛根細咆|リンパ球 }}\right|$ Barr 小体

先天性副腎過形成

\begin{tabular}{c|c|c|c|c}
\hline 1 & 7 日 & 0 & 1 & + \\
\hline 2 & 4 & 0 & 2 & + \\
\hline
\end{tabular}

非進行性女性半院陽

\begin{tabular}{l|l|l|l|l}
\hline 3 & 5 & 5 & 0 & + \\
\hline 4 & 4 & 3 & 0 & + \\
\hline
\end{tabular}

毛根細胞が $5 \%$ とやや高率を示したがそのリンパ球の出 現率は 0 であつた(表 4).つまり, 女性半陰陽に括ける F 小体の出現率は正常女子のそれと同様であるといえる.

vi）真性半陰陽

6 例に打ける検索成績は表 5 亿示した如くである。こ れらのうち 2 例は $46, \mathrm{XY}$ (性腺はいずれも $\mathrm{O}+\mathrm{T}$ )， 2 例 は46, XX (性腺はいずれも OT+OT)，2 例は46, XX/ 46, XY（性腺は 1 例は $\mathrm{O}+\mathrm{OT}$, 他の 1 例は $\mathrm{O}+\mathrm{T}$ ) のモザイク型の karyotype である. 46，XYでは Barr 小体はどちらの症例も $2 \%$ を示して打り, これに対し 毛根細胞あるいはリンパ球の F 小体は26\%和よび24〜48 \%であつた．これは泳その karyotype とも一致して拉 り，その細胞学的性別に関しては男子と考学てよいとい える、ただし F 小体の出現率は低い傾向を認める.46,

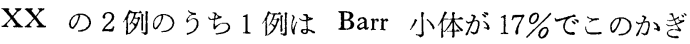
りでは陽性と判定されるし，毛根細胞掞よびリンパ球の F小体は $0.5 \%$ 扒よび $1 \%$ を示した. 他の 1 例も Barr 小体は $12 \%$ これる陽性と判定してょいと考光られ，こ 
表 5 真性半㓌陽に和ける体細胞の $\mathrm{F}$ 小体

\begin{tabular}{|c|c|c|c|c|c|c|c|}
\hline \multirow{2}{*}{ 症 } & \multirow{2}{*}{ 例 } & \multirow{2}{*}{ 年 } & \multirow{2}{*}{ 性 } & $\mathrm{F}$ & 体 & \multirow{2}{*}{$\begin{array}{c}\text { Barr 小体 } \\
\text { （粘膜細胞） }\end{array}$} & \multirow{2}{*}{ 性染色体構成 } \\
\hline & & & & 毛根細胞 & リンパ球 & & \\
\hline & 1 & 10 & $\mathrm{O}+\mathrm{T}$ & $26 / 100$ & $28 / 100$ & $2 / 100$ & $46, \mathrm{XY}$ \\
\hline & 2 & 10 & $\mathrm{OT}+\mathrm{OT}$ & $3 / 100$ & $12 / 300$ & $12 / 100$ & $46, \times x$ \\
\hline & 3 & 31 & $\mathrm{O}+\mathrm{T}$ & - & $24 / 100$ & $2 / 100$ & $46, \quad X Y$ \\
\hline & 4 & 19 & $\mathrm{O}+\mathrm{OT}$ & $15 / 100$ & $19 / 100$ & $9 / 100$ & $46, \mathrm{XX} / 46, \mathrm{X} \mathrm{Y}$ \\
\hline & 5 & 7 & $\mathrm{OT}+\mathrm{OT}$ & $1 / 200$ & $2 / 200$ & $17 / 100$ & $46, \times \times$ \\
\hline & 6 & 28 & $\mathrm{O}+\mathrm{T}$ & $20 / 200$ & $10 / 200$ & $14 / 200$ & $46, \times \times / 46, \times 1$ \\
\hline
\end{tabular}

れに対し毛根細胞拉よびリンパ球のF小体は $1 \%$ 拉よび 4\%であつた。 これらを $46, \mathrm{XX}$ といら染色体組合せと 併せて考学ると，その細胞学的性別はいずれも Barr 小 体出現から一応は女性と判定してよいが，女性としては その出現率はかなり低いといえる，46，XX/46，XY の モザイクを示した 2 例 $(\mathrm{O}+\mathrm{OT}, \mathrm{O}+\mathrm{T})$ のうち，1例 は Barr 小体が $9 \%$ と高率であるとともに毛根細胞持よ びリンパ球の F 小体出現率も15\%和よび19\%と高く，ま た他の 1 例も Barr 小体は $7 \%$ ，毛根細胞叔よびリンパ 球の $\mathrm{F}$ 小体は $10 \%$ 扰よび $5 \%$ を示した。すすおち，モザ イク型のこの 2 例の真性半陰陽では，Barr小体は正常女 子のそれより低いが陽性と判定できないことはなく，一 万F小体も正常男子のそれよりはかなり低いが女子とし てはかなり高率を示しているという興味ある関係が認め られる。

vii）混合型性腺異発生症

この 3 例の karyotypeは 2 例が $45, \mathrm{X} / 46, \mathrm{XY}, 1$ 例が 45，X/46，Xy/46，XY のモザイクを示している（表 6 ).前者のうちの1例では, Barr 小体が1\%であるのに

表 6 混合型性腺異発生症における体細胞の $\mathrm{F}$ 小体

\begin{tabular}{|c|c|c|c|c|c|}
\hline \multirow{2}{*}{ 症例 } & \multirow{2}{*}{ 年令 } & \multicolumn{2}{|c|}{$\mathrm{F}$ 小体 $(\%)$} & \multirow{2}{*}{$\begin{array}{l}\text { Barr } \\
\text { 小休 } \\
(\%)\end{array}$} & \multirow[b]{2}{*}{ 性染色体構成 } \\
\hline & & $\begin{array}{l}\text { 毛根 } \\
\text { 細胞 }\end{array}$ & リン & & \\
\hline 1 & 19 & 40 & 43 & 1 & $45, \begin{array}{l}\mathrm{X} / 46, \mathrm{X} Y \\
(1: 2)\end{array}$ \\
\hline 2 & 30 日 & 5 & 14 & 0 & 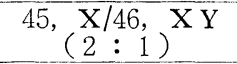 \\
\hline 3 & 1.8 & 7 & 1 & 1 & $\begin{array}{c}45, \mathrm{X} / 46, \mathrm{Xy} / 46 \mathrm{XY} \\
(10: 28: 13)\end{array}$ \\
\hline
\end{tabular}

対し毛根細胞抢よびリンバ球の $\mathrm{F}$ 小体は $40 \%$ 打よび $43 \%$ といらかなり高い出現率を示して括り，このかぎりでは その細胞学的性別はむしろ男といえる。ところが同じ karyotype を示す他の 1 例は Barr 小体が陰性, 毛根細胞 およびリンパ球の F小体はそれぞれ $5 \%$ と $14 \%$ という出
現率で細胞学的性別は男と判定できないこともないが男 としてはかなり低率である。これはあるいは性染色体組 合せの細胞群の割合いのちがいによるのかも知れない。 残りの 1 例は Barr 小体が $1 \%$, 毛根細胞拈よびリンパ 球の $\mathrm{F}$ 小体はそれぞれ $7 \%$ と $1 \%$ といずれも低值を示し て招り，この成績からはその細胞学的性別の判定は非常 にむずかしいということになる．あるいはF小体出現率 の低值は46Xy という細胞群が比較的多いことによるの かもしれない，いずれにしろ，性染色体組合せがモザイ クを示す真性半陰陽の場合とかなり似て打り，とくに混 合型性腺異発生症では Barr 小体抢よび F 小体のどちら かの出現率だけからその細胞学的性別を判定することは さらにむずかしくなつている．これらの所見は，Barr小 体（あるいは drum-stick）だけでなく同時に F 小体をむ 検索して細胞学的性別を総合的汇判定することが，半陰 陽とくに男性（女性）半陰陽か真性半陰陽（あるいは混 合型性腺異発生症）かを診断する上で極めて有用な手が かりを与兄てくれるるのであることを示している。

viii) Klinefelter 症候群

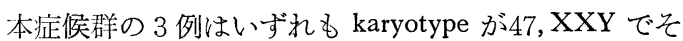
のBarr 小体（むるいは drum-stick） 陽性, 毛根細胞 扣よびリンパ球のF小体出現率は平均それぞれに $65 \%$ 扣よび47\%である（表 7 ）。すなわち，Barr 小体が陽性な のは本症候群の特徵として当然であるが， F 小体もその 出現率は高く，どちらも正常女子あるい怔常男子のそ れと同じである。これは本症候群がその karyotype と一 致してY染色体をるつていることを示するのであるが， F小体技よび Barr 小体が正常男女の どちらにも相当 する值を示している.この点は真性半陰陽扣よび混合型 性腺異発生症の場合と同じょうに細胞学的性別の判定は はほとんど不可能ではあるが，どちらも高率で判定不可 能といらパターンは，47, XXY の Klinefelter 症候群 
表 7 Klinefelter 症候群における体細胞の $\mathrm{F}$ 小体

\begin{tabular}{|c|c|c|c|c|c|}
\hline \multirow{2}{*}{ 症例 } & \multirow{2}{*}{ 年令 } & \multicolumn{2}{|c|}{$\mathrm{F}$ 小体 $(\%)$} & \multirow{2}{*}{ Barr 小体 } & \multirow{2}{*}{ 性染色体構成 } \\
\hline & & $\begin{array}{l}\text { 毛根 } \\
\text { 細胞 }\end{array}$ & $\begin{array}{l}\text { リン } \\
\text { パ球 }\end{array}$ & & \\
\hline 1 & 27 & 81 & 77 & + & 47, X X Y \\
\hline 2 & 17 & 39 & 20 & + & $47, \mathrm{XXY}$ \\
\hline 3 & 17 & 76 & 44 & + & 47, X X Y \\
\hline
\end{tabular}

の診断上，同じく重要な所見とみることができる.

（3）染色体に扣ける $\mathrm{F}$ 小体

上述したようにいろいろなとト細胞核においてQある いは QMなどのアクリジン色素染色で強い蛍光を発する $\mathrm{F}$ 小体が，Y染色体の一部分に相当するということはす でに確かめられた事実である。著者はこれを直接に確認 するため, 本大学医学部染色体異常研究施設の外村教授 に依頼して, ヒト・リンパ球培養細胞の分裂中期の染色 体についてQM染色による検索を行なつた，その所見は 写真 6 の如くで, 明らかにY 染色体の長腕の一部（遠端 部）がはつきりとほかの部分あるいはほかの染色体と識 別できるほど強く䖢光染色されている.

\section{総括と考案}

緒言にも述べたように，F小体 (fluorescent body) の 発見はアクリジン系の䖝光色素, とくに quinacrine mustard dihydrochloride $(\mathrm{QM})$, quinacrine dihydrochloride (Q) あるいは propyl quinacrine mustard dihydrochloride (PQM) などによる染色法を用いての植物抽よび動物細 胞構造の研究に端を発したものである.これら一連の 研究が発展して,さらにヒト細胞の $\mathrm{Y}$ 染色体の長腕の遠 端半分のみがこれら蛍光色素によつてほかの部分とはつ きり識別でさるほど強い蛍光を呈することが確かめられ たが，そればかりでなく分裂休止期のヒト細胞核内にも 同じく強い蛍光を発する小体として識別できることが明 らかにされ，臨床的にもその応用が注目されるに至つた ものである.

著者も当大学染色体異常研究施設の外村教授らの好意 で，ヒト・リンパ球の培養による分裂中期のY 染色体長 腕の一部がこれら䖢光色素によつて明瞭に染色されると いう成績を確認することができた (写真 6 を参照).そこ で著者はさらに, ヒトの細胞（表皮,リンパ球あるい精 子）についてQあるいは QMVよる染色法で F 小体の検 索を行なつた，その成績は第 3 章に記述した如くである がここにはこれら成績を総括するとともに若干の考察
を加壳てみたい。

これら监光色素によつて，なぜある染色体の一部分だ ケが蛍光䫓微鏡ではつきり識別できるほど強く染色され るかについては，現在次のように解释されている．はじ

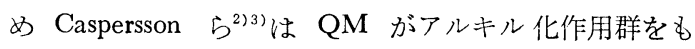
ち，これが染色体の guanine の N-7の原子飞結合すると いらことから, guanine の多い DNA の部分, さらに一 般的には DNA の多い染色体部分に結合するためと考兄 た.しかし，その後の研究からこの解釈は正当ではな く，QMで染色される部位は heterochromatin で構成 されているためといゔ説が有力になつている5゙. hetrochromatin とは性染色体ではじめて発見されたものであ る.これは heterochromosome ともよばれ，細胞分裂の 終りにも濃縮したまむで残り染色体を失われないでいる という性状をもつている ${ }^{10)}$. ところが，その後の研究で 常染色体にも分裂の間に濃縮されたまま残る部分のある ことが判明した。 このような部分はすべて heterochromatinとよばれ，そらでない染色体部分は euchromatin

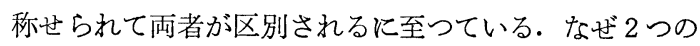
異なる chromatin が存在するかはまだいろいろと議論の あるところだが，恐らく heterochromatin とは染色体の 各節の作用を発動させる機能をもつ部分であり，いいか えれば heterochromatin そのものは遺伝学的には機能を るつていないと解される. あるいは, heterochromatin の細胞学的定義によれば，これは interphase の核に捛 ける濃缩され DNAを多量に含む部分といらことにもな る.ある種のアクリジン色素で染色された染色体を蛍光 顕微鏡でみるとその部分部分が幾涤にも蛍光を発した帯 状を呈するが，この蛍光帯は heterochromatin の部分に 相当すると考元られている．とくに Q, QM などにこの 作用が強いのはイオン結合 (ionic bonding) と intercalation によつて DNA に結合しやすい性状をもち，なか でも QM はそのもつアルキル化作用群によつて一層DNA との結びつきが強いのではないかと考兄られている. しかし， Qや QMの DNA 結合力は動物の種類によつて ちがつているらしい，たと兊ば，著者も確認したよう に, QやQMによつてY染色体や七ト精子の約半数では $\mathrm{F}$ 小体がはつさり染色されるのに, ウシ精子ではこの現 象が見られないといら caprine はダイズやハムスターの染色体を均等に染色す るが，ヒトの染色体では帯状に染色されているといらち がいのあることも確かめられている ${ }^{14)}$. 以上のいるいる な研究成績から考案すると, ヒトのY染色体およびinter- 
Phase の細胞核内にみられるQや QM で強く染色される 部分, 寸なわち $\mathrm{F}$ 小体とよばれるものはこれら蛍光色素 にとくにいわゆる親和性をもつ heterochromatin の部分 と見ることがでさよう.

Caspersson $5^{23)}$ も指摘しているように, この F 小体 の染色にはQMの方が $\mathrm{Q}$ より強い蛍光を発し，安定性も 大きく褪色が抢そいとされて和り，このことは著者も確 認している．これは恐らくQMがアルキル化作用群をも つているためかとも考光られるが，著者の実験によれば $\mathrm{Q}$ も $\mathrm{F}$ 小体の検索には十分役立つことを確認している. したがって，できるならQMの方がよいが，Qでも臨床 的には十分応用できるものといえる.

以上のようなことから, 著者は正常男女, 性器異常 （男子不妊症，尿道下裂，停留辠丸，各型の半陰陽，性 染色体異常症）などに打いて主として毛根細胞, 血液り ンパ球など休止期細胞 特よび精子につき，Qあるいは $\mathrm{QM}$ 染色による $\mathrm{F}$ 小体の出現を蛍光顕微鏡によつて検索 した．血液についてリンパ球を対象としたのは，既述の ように多形核白血球よりは，はつきりから容易にF小体 の存在を判定できるからである ${ }^{915) 16)}$.

\section{正常男女における F小体}

男子の場合, その毛根細胞扝よびリンパ球の核には, $\mathrm{Q}$ なた $\mathrm{QM}$ で強く染色される直径約 $0.2 \sim 0.3 \mu$ の円 形の F 小体が約30～70\% に存在する. しかし，女子の場 合には全く存在しないか， F小体と推定されるものが認 められてもとの出現率はせいぜい $3 \%$ それい下である

（図 2，3，4）.この所見は男女の体細胞核の F 小体の 出現がはつきりちがつていることを示すものである。い い兄ると，ヒ卜体細胞核に淤る $\mathrm{F}$ 小体の検査は Barr 小体 (sex chromatin) 検查と同様, とくにこれとの併用 によつて細胞学的性別 (cytological sex) の判定に極め て有用な臨床的検査法である。ただ，なぜ男子にもつと 高率に出現しないか，逆に女子でもなぜ稀れではあるが 時には $4 \sim 5 \%$ の出現を示すのか，この点は sex chromatin 検查成績の実態とよく似ている ${ }^{8)}$ ここれにはいる いろの原因や解釈が考光られるが，これらの検查法はど ちらも性別の判定といらヒトの一生をも左右する汪どの 重大な決定の基準ともいえるものである. したがつて, その判定には少しでも疑念を残さないようにすることが 最も肝要である.これにはよい標本, よい顕微鏡, よい 観察者といらことが最大の条件となる、ただ図 4 亿示し たように座標図式で毛根細胞とリンパ球の出現率をプロ ットすると，F小体出現率は男女の間ではつきり区別さ
れることが判明している。したがつて，正確を期するた めには同一人につき毛根細胞（その他の細胞でもよい） とリンパ球の $\mathrm{F}$ 小体を検查してこれを総合的に判断する のがよいと考兄られる。な拉，妊娠初期の頝管粘膜 ${ }^{20)}$, あるいは羊水中細胞 ${ }^{17}$ の F 小体査検による性別判定の可 能性も想定されており, 将来はこの方面でも有力な検査 法となるであるう。

\section{精子における F小体}

精子にはX精子とY 精子の 2 種類が存在することはす でに周知のと扔りである．したがつて，F小体が $\mathrm{Y}$ 染色 体を示するのであるとすれば，精子をQあるいはQMで 染色すれば F 小体をもつ精子を区別することができるは ずであり，実際にも精子のらちにはF小体をもつものが 40～50\%の割合いで存在することが証明されている ${ }^{13) 14}$, 21). 著者も正常叔よび不妊を主訴とするそ精子症の射精 液中の精子について $\mathrm{F}$ 小体の出現率を検索した．その結 果, $40 \%$ 前後の精子は 1 個の F 小体をもつていることを 認め,さらにこの出現率は精子数あるいは精子の運動性 などとの間に相関関係を示していないことをも確かめた (写真 4 拈よび因 5，6).この成績は Pearson ら ${ }^{14)}$, Barlow ら ${ }^{1)}$, Summer ら ${ }^{21)}$ のそれと同様であつた. しか 乙既述の上うにY染色体の長腕の一部が強く営光染色さ れるからといつて F 小体をもつ精子が $\mathrm{Y}$ 精子，これを欠 くものがX精子だということは，この蛍光染色法による かぎり，それは間接的な証明であることはいらまでもな い.これに対し Summer ら ら11は，F小体をるつY精子 と想定されるものとこれをもたないX精子と想定される ものとにつき Feulgen 染色による DNA 含有量の測定を 行なつて比較検索した．この検索から，F小体陽性の精 子と陰性の精子との間の DNA の量的差異は $23 \mathrm{X}$ と23Y の haploid 間で理論的に算出した量的差異と等しいこと を確かめている。つまり， F 小体陽性の精子はY 染色体 をもつ精子と考光てよいことになる。な扐，著者の $40 \%$ 前後が F 陽性精子といら出現率は Pearson ら ${ }^{14)}$ な゙のと れよりやや低率ではあるが，Diasio \& Glass ${ }^{6}$ のそれに ほぼ同じ数值である.これは恐らくQMの使用とか検查 法の習熟度を高めることで理論的に想定される50\%前後 の出現率が得られるかも知れないが，少なくとも著者の 成績からも射精液中の精子の約半分は $\mathrm{Y}$ 精子であると考 えてよいといえる.

このようにY 精子は通常 1 個の F 小体をもつているわ けであるが，著者の検索によるとそのらちの 8 例（正常 4 例, 乏精子症 4 例）飞扔いては 2 個の F 小体をもつ精 
子の存在することを認めているそその出現率は $1-3 \%$ (平均 1.8\%) であつた Pearson \& Barlow ${ }^{14)}$ は 3 例の 正常男子の精子細胞 (Spermatid) の $1.4 \%$ が 2 個の F 小体をるつ精子であることをまた Summer ${ }^{21}$ らもほぼ 精子の $1.26 \%$ が 2 個の F 小体をるつていることを報告し ている．著者の47例についての精子に打ける $\mathrm{F}$ 小体検索 で，8例にの及平均 $1.8 \%$ に 2 個の F 小体をもつ精子の あることを認めたのはなぜか，はつきり断定はできない が, 各例とも 100〜 200の精子を検索しているからで, 同一精液につきもつと多数の精子を検索すれば，さらに 高率に発見されるかも知れない。これに対し, Diasio \& Glass $^{6)}$ は XYY の 1 例でその精子の $5 \%$ が 2 個の F 小 体をもつているのを認めたが，それ以外では 5,700 個の 精子を検索して 2 個の F 小体をもつものは 1 個も発見で きなかつたという．この点もさらに今後の検討が必要で あろう. しかし, 一見正常と考えられる男子の精子中に も 2 個の F 小体をもつものが平均 $1.8 \%$ も存在すること があるといら事実は注目に価する。それにもかかわら ず，XYY という性染色体組合せ異常の発生は $0.1 \%$ 以 下と算定されている。 これは恐らく，2 個の F 小体をも つ精子は 1 個しかない正常の $\mathrm{Y}$ 精子より授精能力が低 いといらことも推定される ${ }^{21)}$. これに関して著者は 2 個 の F 小体をるつY 精子はその形態に異常を示しているも のの方にはるかに多いという成績を得ており（写真 5 ）， これも 2 個の F 小体をもつ精子が実際には授精しにくい ことの証左と考光ることもできる.

\section{性器系異常}

単純性尿道下裂括よび停留睪丸では，体細胞飞おける $\mathrm{F}$ 小体の出現率はそれぞれ毛根細胞で $66.2 \%$ と $62.6 \%$, リンパ球で $49.8 \%$ と $60.2 \%$ でありこれは正常男子のそ れらと全く同様であつた。 また男性半陰陽の診断が確定 したものでは, 体細胞の F 小体は正常男子および単純性 尿道下裂とほ注同じ出現率を示し，F小体に関するかぎ り異常は認められていない。これに対し，先天性副腎過 形成症または非進行性男性化症を含む女性半陰陽ではい ずれも体細胞の F 小体の出現率は正常女子の場合之同様 で，少数の例外（3〜 $5 \%$ ）をのぞきその大部分では出 現率が 0 であつた。

しかし, 真性半陰陽および混合型性腺異発生症では $\mathrm{F}$ 小体の出現および Barr 小体の出現の率とか割合いなど

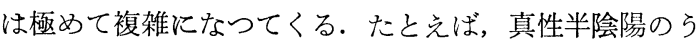
ち46, XY の 2 例（性腺：O+T）ではF小体は $26 \%$ お よび24〜28\%であり Barr 小体は $2 \%$ であつた. karyo- type が46, XX の 2 例（性腺: OT + OT) の真性半陰 陽では Barr 小体が12\%拉よび17\%で明らかに陽性，と ころが毛根細胞での F 小体は $3 \%$ 抢よび $0.5 \%$, リンパ 球では $4 \%$ および 1\%の出現率を示していた．46，XY の症例では Barr 小体抢よび $\mathrm{F}$ 小体の出現率は大よそそ の karyotype をそのまま示して抢り，その細胞学的性別 は一応男性と判定されるが，F小体の出現率は正常男子 のそれよりはかなり低率である。これと対応するよう に，46，XX ではその細胞学的性別は karyotype とほぼ 相応し女性型に近いが， Barr 小体は陽性とは判定でき るが，その出現率は $12 \%$ 拈よび17\%と正常女子の報合よ りはやはり低い傾向を示している，つまり，Barr 小体 あるいはF小体の出現率は大体に执いてそれぞれの karyotype を反映してはいるが，異性半陰陽あるいは女性半 陽陰の場合とはかなりらがつており，これらの出現率は はつきりと細胞学的性別を示すものとしては一般に低い 傾向を示している．このような所見と性腺分化の異常と の関係は今後検索例の増加によつて明らかになると考光 られるが，少なくともモザイク型でない真性半陰陽の Barr 小体と $\mathrm{F}$ 小体の出現率とかとの割合いは男性半陰 陽のそれとはかなりちがらパターンを示しているといえ る. したがつて Barr 小体と併施した $\mathrm{F}$ 小体の検索は真 性半陰陽の鑑別彰断に新しい一つの手段を提供するも のといえる．このような Barr 小体と F 小体の出現率と かその割合いの特異的なパターンは $46, \mathrm{XX} / 46, \mathrm{XY}$ の モザイク型の真性半陰陽の 2 例（性腺: O+OT とO+ T) ではさらにはつきりしている。すすなわち，その1例 は Barr 小体 $9 \%$ で陽性之判定されるにもかかわらず F 小体も15〜19\%というかなり高い出現率を示している. もう1 例は Barr 小体が $7 \%$ で陽性であるとともに，F 小体もかなり低いが10\%拈よび5\%と女性としてはやや 高い出現率である.この 2 例の場合に抢ける細胞学的性 別判定は当然困難になつてくるが，逆にみれば Barr 小 体のみならず $\mathrm{F}$ 小体の雨方を総合した成績からの判定が 困難のような半陰陽はむしろ真性半陰陽の可能性が大き いことを示唆する所見とも考劣ることができる（表 5 ）．

同様のことは karyotype がモザイクを示す混合型性腺 異発生症 ${ }^{12}$ についてもい光るし，そのパターンは一そう 複雑で Barr 小体执よび F 小体による細胞学的判定はさ らに困難になつてくる.すなわち， 2 例の $45 ， \mathrm{X} / 46$, XY および1例の $45 ， \mathrm{X} / 46 ， \mathrm{Xy} / 46 ， \mathrm{XY}$ に和ける Barr 小体抢よび $\mathrm{F}$ 小体の出現率はどちらもとの割合 いからいつて細胞学的性別判定が一そう難かしいという 
所見を呈している（表 6).したがつて，これらの所見も Barr 小体打よび $\mathrm{F}$ 小体による性別判定の困難さがモザ イク型の半陰陽を示唆するといらことを裏づけている.

著者の検索した Klinefelter 症候群の 3 例は karyotype がいずれも47，XXY であるが，これらでは Barr 小体 は女性系に近い高率で明らかに陽性であり，同時にF小 体も男性のそれと判定してよい高率を示している。これ もBarr 小体拈よびF小体からの性別判定は困難ではあ るが，ただ真性半陰陽あるい惃合型性腺異発生症のパ ターンとは著しく趣きを異にして括り, 細胞学的にはと のどちらだ仍からも男とも女とも判定でさる活ど両者が 高率である.

\section{結 論}

正常男女, 種々の性器系異常症などのヒト細胞（毛根 細胞, リンパ球, 精子) について quinacrine dihydrochloride(Q)あるいは quinacrine mustard dihydrochloride $(\mathrm{QM})$ 染色と蛍光顕微鏡により, $\mathrm{Y}$ 染色体を示すとされ る蛍光小体 (fluorescent body: F 小体) の検索を行なつ た.

（1）リンパ球培盖による分裂中期の染色体について 検索した結果， $\mathrm{Y}$ 染色体の長腕部（遠端の半分）のみ が，QあるいはQMによつて強い蛍光を発する.

（2）正常男子の毛根細胞およびリンパ球扎括いて も，明らかにその核内に 1 個の直径約 $0.2 \sim 0.3 \mu$ の円 形あるいは長棈円形の強い蛍光を発する小体 (F 小体) が平均30〜 40\%以上に認められる.これに対し正常女子 の場合は時に $2 \sim 3 \%$ F 小体を認めるが大部分では全 く存在しない.したがつて, 体細胞核に和ける F小体の 検索は, Barr 小体 (sex chromatin) 検査と同じく, め るいは両者の併施は細胞学的性別の判定に極めて有用な 検查法である. 正確を期するためには毛根細胞とリンパ 球の両者についてF 小体を検查し総合的に判断するのが よい.

（3）射精液中の全精子数のらち30４0\%（大部分は $40 \%$ 前後）にY 精子と想定される1個の F 小体をるつ精 子が存在する。この出現率は正常およびそ精子症に和け る精子数あるいは精子運動率との間に相関関係を示して いない. 8 例（正常 4 例，泛精子症 4 例）において平均 $1.8 \%$ 亿 2 個の $\mathrm{F}$ 小体をもつ精子の存在することを認め た. しかし，2個の F 小体をもつ精子はむしろ正常精子 よりは形態異常を示す精子の方に多く認められる。

（4）男子不妊症, 単純性尿道下裂, 停留辠丸, 男性 半陰陽では体細胞の $\mathrm{F}$ 小体出現率は正常男子のそれと同
じであり，逆に女性半陰陽の場合は正常女子と同じ出現 率を示した.

（5）真性半陰陽ではその karyotype にある程度まで 対応して Barr 小体木たはF小体の出現率が高いが，正 常の男女にくらべるといずれも低率である．モザイク型 の真性半陰陽年るいは混合型性腺異発生症に括いては,

Barr 小体あるいはF小体の出現率は, 不定の傾向が強 くどちらも全体として低率であり, 細胞学的性別の判定 が困難である．したがつて，Barr小体 (sex chromatin) 括よび $\mathrm{F}$ 小体の検索成績で性別判定が困難のような場合 は, むしろ真性半陰陽とかモザイク型の混合型性腺異発 生症などを疑わせる有力な所見ともい党る。

（6） Klinefelter 症候群 (いずれも47, XXY) での $\mathrm{F}$ 小体は正常男子のそれと同様で高率を示し, また Barr 小体 (sex chromatin) も陽性であつた. 細胞学的性別判 定が困難な点は真性半陰陽や混合型性腺異発生症と同様 であるが，本症候群は常に F 小体の出現率が高いという 異なるパターンを示している.

本研究に関して恩師落合京一郎教授より絶大な御指導 と御校閲を睗わつた。 また本学附属遺伝病研究施設染色 体異常研究部の外村晶教授, 山田博士から絶大な御指導 と御援助を賜つたほか当教室の駒瀬講師, 大島講師, 根 岸講師, 佐々木㛄ならびに教室員諸氏の御助力をいただ いた。ここに深く感謝の意を表する。

本諭文の一部 1971 年 9 月16日第 336回日本泌尿器 科学会東京地方会, 同年10月15日第16回日本不妊学会総 会, 同年10月31日第36回日本泌尿器科学会東部連合地方 会に拈いて発表した。

\section{文献}

1) Barlow, P. and Vosa, C.G.: Nature, 226, 961, 1970.

2) Caspersson, T., Farber, S., Foley, G.E., Kudynowski, J., Modest, E.J., Simonsson, E., Wagh, U. and Zech, L.: Exptl. Cell Res., 49, 219, 1968.

3) Caspersson, T., Zech, L., Modest, E.J., Foley, G.E., Wagh, U. and Simonsson, E.: Exptl. Cell Res., 58, 128, 1969.

4) Caspersson, T., Zech, L., Modest, E.J., Foley, G.E., Wagh, U and Simonson, E.: Exptl. Cell Res., 58, 141, 1969.

5) Caspersson, T., Zech, L. and Johansson, C.: Exptl. Cell Res., 62, 490, 1971.

6) Diasio, R.B. and Glass, R.H.: Lancet, ii, 1318, 1970.

7) George, K.P.: Nature, 226, 80, 1970. 
8）金井三郎：日泌尿会誌，49，187，1958.

9) Lamborot-Manzur, M., Tishler, P.V. and Atkins, L.: Lancet, i, 974, 1971.

10) Mittwoch, V.: Sex Chromosomes, London, 1967.

11) Meredith, R.: Chromosoma, 26, 254, 1969.

12) 落合京一郎: 半陰陽, 現代産婦人科学大系, II, 中山萻店, 1971.

13) Pearson, P.L., Bobrow, M. and Vosa, C.G.: Nature, 226, 78, 1970.

14) Pearson, P.L. and Barlow, M.: J. Reprod. Fert., 22, 107, 1970.

15) Polani, P.E. and Mutton, D.E.: Brit. Med.
J., i, 138, 1971.

16) Ricci, N., Castoldi, G.L., Dallopiccola, B. and Baserga, A.: Brit. Med. J., i, 347, 1931.

17) Rook, A. Hsu, L.Y., Gertner, M. and Hirschhorn, K.: Nature, 230, 53, 1971.

18) Schmidt, W.: Cytogenetics, 6, 342, 1967.

19) Sperling, K.: Lancet, i, 753, 1971.

20) Schettles, L.B.: Nature, 230, 52, 1971.

21) Summer, A.T., Robinson, J.A. and Evans, H.J.: Nature New Biology, 229, 231, 1971.

22) Zech, L.: Exptl. Cell Res., 58, 463, 1969.

(1972年 2 月14日受付) 